\title{
Estimating Environmental Impact Potential of Small Scale Fish Processing Using Life Cycle Assessment
}

\author{
Rahayu Siwi Dwi Astuti ${ }^{1}$, Hady Hadiyanto ${ }^{1,2^{*}}$ \\ 1 Master Program of Environmental Studies, School of Postgraduate Studies Diponegoro University, \\ Semarang, Indonesia \\ ${ }^{2}$ Chemical Engineering Departement, Faculty of Engineering Diponegoro University, Semarang, Indonesia \\ * Corresponding author's e-mail: hadiyanto@live.undip.ac.id
}

\begin{abstract}
Post-harvest handling / processing of fishery commodities requires large amounts of water and energy to overcome their perishable properties. Water is needed as raw/auxiliary material and to ensure that the production process and its environment meet the sanitary and hygiene principles. Meanwhile, large amount of energy is required for the transportation of raw materials and products, cold chain system during the process and operations of processing machines. They contribute towards the environmental impact of fish processing. This study used life cycle assessment to estimate the potential environmental impact of small scale mackerel fish processing. The results showed that the fish processing has contributed to $0.079 \mathrm{~kg} \mathrm{SO}_{2}$ eq acidification potential, $9.66 \mathrm{~kg} \mathrm{CO}_{2}$ eq climate changGWP 100, $0.02 \mathrm{~kg} \mathrm{PO}_{4}$ eq Eutrophication-generic, $0.17 \mathrm{~kg} 1.4$ DCB eq human toxicity-HTP inf, and $0.0015 \mathrm{~kg}$ ethylene eq photochemical oxidation-high $\mathrm{NO}_{\mathrm{x}}$. Wastewater treatment implementation simulation showed elimination of direct emissions that contribute to eutrophication and increasing the potential of other process associated with energy consumption.
\end{abstract}

Keyword: wastewater treatment, fish processing, life cycle assessment

\section{INTRODUCTION}

The life cycle of a fishery product begins with the capture. When fish are removed from the ocean, cold chain systems and sanitation guarantees are required. The perishable nature of fishery commodities requires hygienic and cold chain conditions for their handling. As a consequence, the handling process need large amount of water and energy, and in turn produce large volumes of wastewater as well (Hall \& Kose 2014). Hall and Kose (2014) describe four common problems of sustainability in fisheries processing technology, which include energy consumption, water consumption, waste control and by-product development. Water usage in the pretreatment stage includes the process of handling fresh fish storage, weeding process as well as cleaning equipment and work area (Doorn et al. 2006, Duangpaseuth et al., 2010). The generated wastewater contains organic matter (fat, protein and suspended solids), phosphate and high amount of nitrates (Duangpaseuth et al., 2010). Energy is used to operate machinery, produce ice, heating, cooling and drying (Arvanitoyannis \& Kassaveti 2008).

Considering the high amount of organic material, an effective method for treating the industrial waste is a biological treatment, but it must be conducted under optimum conditions (Sunny \& Mathai 2013). One of the wastewater treatment methods of food industry that contain high amount of organic matter is anaerobic-aerobic biofilter method. This method is believed to have high waste degradation efficiency, reach up to $95 \%$. Integration of these two methods, in addition to providing better results, can also reduce the energy consumption and sludge production (Sunny \& Mathai 2013, Said 2017). At the anaerobic stage, the organic pollutants in the waste water are decomposed into $\mathrm{CO}_{2}$ gas without energy use, but ammonia and $\mathrm{H}_{2} \mathrm{~S}$ are not removed. Furthermore, the un- 
organized organic material remains, described in the aerobic stage, in which the organic material is decomposed into $\mathrm{CO}_{2}$ and water, ammonia to nitrite and subsequently nitrates, and $\mathrm{H}_{2} \mathrm{~S}$ into sulfate (Said 2017).

The decomposition process at the anaerobic stage involves 4 groups of bacteria, namely hydrolytic bacteria, fermentative acidogen bacteria, acetogenic bacteria and methanogenic bacteria. These four bacteria convert organic matter into $\mathrm{CH}_{4}$ and $\mathrm{CO}_{2}$, as well as a little $\mathrm{NH}_{3}, \mathrm{H}_{2}$ and $\mathrm{H}_{2} \mathrm{~S}$ (Said 2017). At the aerobic stage, the bacterial metabolism process breaks down organic materials into a simple form of $\mathrm{CO}_{2}, \mathrm{H}_{2} \mathrm{O}$, oxide compounds such as nitrates, sulfates, phosphates and the formation of new cell mass. In general, the reaction is (Said 2017):

Organic compounds $+\mathrm{O}_{2} \rightarrow \mathrm{CO}_{2}+\mathrm{H}_{2} \mathrm{O}+$ + new cells + energy

The main processes used in wastewater treatment to reduce nitrogen are nitrification and denitrification, involving autotrophic bacteria. During nitrification, ammonia is converted to nitrites by nitrosomonas bacteria; then, nitrites are converted to nitrate by nitrobacterial bacteria. In this process, $\mathrm{N}_{2} \mathrm{O}$ can be produced even if it is not an intermediate product. The nitrification process requires a considerable amount of oxygen $-3.43 \mathrm{~g}$ to oxidize nitrogen to nitrite, and $1.14 \mathrm{~g}$ to oxidize nitrogen to nitrate (Said 2017, Snip 2010).

Denitrification occurs under anoxic conditions, where heterotrophic bacteria use nitrate, nitrite, nitric oxide and nitrous oxide as electron acceptor. In this process $\mathrm{N}_{2} \mathrm{O}$ becomes an intermediate material. Thus, $\mathrm{N}_{2} \mathrm{O}$ can be produced and released by the imperfect denitrification process (Snip 2010, Said 2017).

$$
\mathrm{NO}_{3}{ }^{-} \rightarrow \mathrm{NO}_{3}{ }^{-} \rightarrow \mathrm{NO} \rightarrow \mathrm{N}_{2} \mathrm{O} \rightarrow \mathrm{N}_{2}
$$

A method used to assess potential environmental impact of a fishery product system is Life Cycle Assessment (LCA). ISO 140401997 explains that LCA is a technique to assess the environmental aspects and potential impacts of a product. LCA is carried out throughout the product life cycle, including raw material extraction, production process, usage to waste disposal (cradle to grave). The categories of environmental impact common to LCA are the use of resources, human health and ecological consequences. LCA can be utilized in (International assessment Principles and framework, 1997):
1. Identification of the opportunities to improve the environmental aspects of a product throughout its lifecycle,

2. Decision making in industry or organization

3. Marketing (e.g. providing support in the form of claims for environmental performance)

The scope of the LCA study on a system of fishery products includes pre-manufacture, manufacture, packaging and distribution, and end use. The assessment can be based on the energy and water consumption and waste production. The six common categories of environmental impacts in LCA of the fisheries industries are global warming, acidification, eutrophication, ozone depletion, land use and photochemical smog (Hall \& Kose 2014).

Energy consumption in pre-manufacturing stage is the use of fuel in the process of fish catching and transporting from the landing site to a fish processing plant. The formulas to estimate emission of a fishing vessel energy consumption are provided in Boer, et al. (Rizaldi Boer et al., 2012). Meanwhile, the consumption of electrical energy is related to the indirect emissions generated. The emission was estimated using Widiyanto, et al. (Widiyanto, Kato, \& Maruyana, 2003) models.

Other environmental impacts connected to fisheries products system that deserve attention is the waste produced, both solid and wastewater. The proportion of solid waste depends on the proportion of the body of each species of fish and the type of product. The wastewater depends on the water volume used and fish processing method. Generally, water is mostly used in fish washing and the process of maintaining sanitation and hygiene of machinery and equipment, as well as rooms and employees. The fish processing wastewater contains contaminants in soluble, colloid and particulate forms, high BOD content, fat, and mineral (Tay et al. 2004). Fish filleting can produce 1-3 $\mathrm{m}^{3}$ of waste water with COD content of 4-15 kg (Arvanitoyannis \& Kassaveti 2008). The high organic matter released into the environment has the potential of causing eutrophication.

Life cycle processes of wastewater treatment facility, as described previously, produce emissions either directly due to biological processes or indirectly as a result of energy consumption. Assessment of the potential environmental impacts of the life cycle of some wastewater treatment plants had been done in several places using the 
LCA (Foley et al. 2010; Glick et al. 2005; Kalbar et al. 2013; Snip 2010). Glick dan Guggemos (2013) used the LCA to estimate the environmental impact of the manufacturing, construction, usage and maintenance phase of the facility.

As previously described, the major emissions generated in biological waste processing are $\mathrm{CH}_{4}$, $\mathrm{CO}_{2}$ and $\mathrm{N}_{2} \mathrm{O} . \mathrm{CH}_{4}$ and $\mathrm{N}_{2} \mathrm{O}$ have high GWP values, while the resulting $\mathrm{CO}_{2}$ is considered safe because it is biogenic origin. IPCC, 2001, noted that $\mathrm{CH}_{4}$ has 23 value of GWP and $\mathrm{N}_{2} \mathrm{O}$ has 296 values of GWP (Midgley et al. 2001).

The aims of this study are to assess the environmental impacts of amplang processing, and what are the potential environmental impacts when a sewage treatment facility is implemented in an amplang product system.

\section{RESEARCH METHODOLOGY}

\section{System boundary and functional unit}

The study was conducted at a fish processing SME in Kumai Sub-district in July 2017, using the secondary data obtained from SMEs and the primary data for liquid waste analysis. In addition to the data to sourced from SME financial reports, it was also acquired from interviews with business owners of processing and fishing.

The data analysis conducted in this study using the LCA method "cradle to gate", i.e. from the stage of arrest until production (Figure 1). The functional unit used was $1 \mathrm{~kg}$ amplang.

\section{Life Cycle Inventory}

The analysis was restricted to energy, water and raw fish consumption, excluding environmental loads of other raw materials, packaging plastics and transportation. The formulas to estimate emissions from fuel consumption for sea transport, i.e. (Sunny et al. 2015) are as follows:

Tier-2: Emission =

$\sum_{a b}$ fuel consumption $_{a b} \times N K_{a} \times E F_{a b}$

where: Emission $=$ emission of $\mathrm{CO}_{2}, \mathrm{CH}_{4}$ or $\mathrm{N}_{2} \mathrm{O}$ Fuel consumption $_{a b}=$ vessel fuel consumption

$N K_{a}=$ fuel caloric value a

$E F_{a}=$ Emission factor of $\mathrm{CO}_{2}, \mathrm{CH}_{4}$ or $\mathrm{N}_{2} \mathrm{O}$ according to fuel type $(\mathrm{kg} / \mathrm{TJ})$ (Table 1$)$

$a=$ fuel type (solar, IDO etc.)

$b=$ vessel $/$ motor type

Emissions per $1 \mathrm{~kW}$ of electrical energy generated were estimated using a model developed by Widiyanto et al. (2003) and shown in Table 2.

Table 1. Typical emission factor for river/sea vessel in Indonesian cities using Tier-2 (Suhadi \& Febrina 2013)

\begin{tabular}{|c|c|c|}
\hline Parameter & Unit & Emission \\
\hline $\mathrm{NO}_{x}$ & $\mathrm{~kg} /$ ton of fuel & 57.1 \\
\hline $\mathrm{CO}$ & $\mathrm{kg} / \mathrm{ton}$ of fuel & 19.8 \\
\hline $\mathrm{CO}_{2+}$ & $\mathrm{kg} / \mathrm{GJ}$ & 74.1 \\
\hline $\mathrm{HC}$ & $\mathrm{kg} / \mathrm{ton}$ of fuel & 7.45 \\
\hline $\mathrm{SO}_{x}$ & $\mathrm{~kg} /$ ton of fuel & $2 \times \% \mathrm{~S} \times \mathrm{FCm}$ \\
\hline $\mathrm{PM}_{10}$ & $\mathrm{~kg} /$ ton of fuel & 4.6 \\
\hline
\end{tabular}

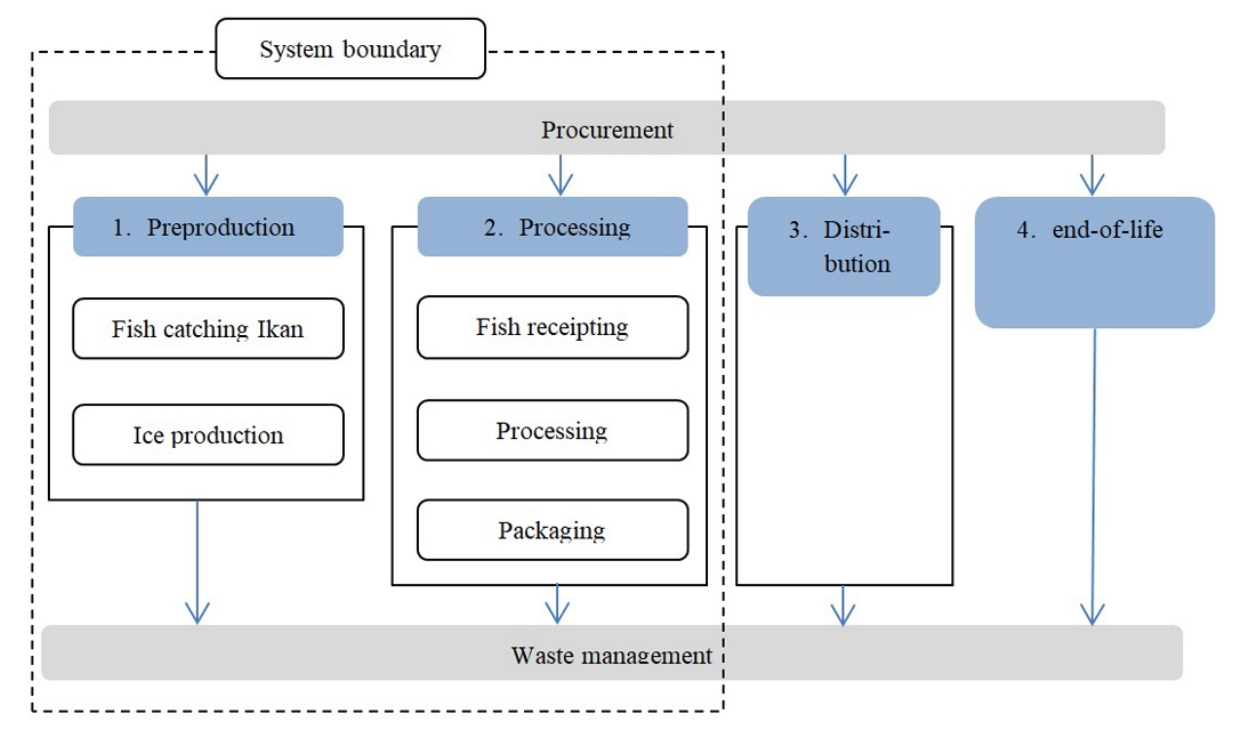

Fig. 1. Amplang production system 
Table 2. Direct Emissions Measurement of Fuel Burning at Power Plant (Widiyanto et al. 2003)

\begin{tabular}{|c|c|c|c|}
\hline \multirow{2}{*}{ Emission } & \multicolumn{3}{|c|}{ Eletricity generation $(\mathrm{kg} / \mathrm{kWh})$} \\
\cline { 2 - 4 } & 1 & 2 & 3 \\
\hline $\mathrm{CO}_{2}$ & $9.22 \times 10^{-1}$ & $9.22 \times 10^{-1}$ & $7.72 \times 10^{-1}$ \\
\hline $\mathrm{SO}_{2}$ & $4.36 \times 10^{-3}$ & $3.99 \times 10^{-3}$ & $2.01 \times 10^{-3}$ \\
\hline $\mathrm{NO}_{\mathrm{x}}$ & $4.39 \times 10^{-3}$ & $4.19 \times 10^{-3}$ & $3.64 \times 10^{-3}$ \\
\hline $\mathrm{SPM}$ & $6.70 \times 10^{-4}$ & $6.12 \times 10^{-4}$ & $2.19 \times 10^{-4}$ \\
\hline $\mathrm{N}_{2} \mathrm{O}$ & $4.25 \times 10^{-5}$ & $3.64 \times 10^{-5}$ & $4.68 \times 10^{-4}$ \\
\hline $\mathrm{NMHC}^{\mathrm{CH}}$ & $3.20 \times 10^{-5}$ & $3.20 \times 10^{-5}$ & $3.83 \times 10^{-5}$ \\
\hline $\mathrm{CO}$ & $1.13 \times 10^{-5}$ & $1.03 \times 10^{-5}$ & $1.64 \times 10^{-4}$ \\
\hline
\end{tabular}

Information:

$1=\quad$ Coal steam turbine; using Bukit Asam coal (Sumatra) (in a $600 \mathrm{MW}$ power plant)

$2=\quad$ Coal steam turbine; using Kalimantan coal (in a $600 \mathrm{MW}$ power plant)

$3=\quad$ Indonesia's diesel-fueled power plant.

The wastewater content was obtained through the waste sample test, and the sample was taken by grab sampling.

\section{Life cycle impact assessment of amplang poduction system}

The input and output data of amplang production system were analyzed using an OpenLCA application developed by Green Delta with the methodology of CML (baseline) [v4.4, January 2015].

Predesigning and conducting life cycle inventory of small wastewater treatment plant

The second step in this study was to conduct a theoretical wastewater treatment plant predesign. On the basis of this predesign, the emissions produced were estimated either directly or indirectly. The $\mathrm{CH}_{4}$ and $\mathrm{N}_{2} \mathrm{O}$ emissions were calculated using the Tier 2 formula in IPCC 2006 and Guidelines for National Greenhouse Gas Inventory Book II. On the other hand, the emissions from electricity consumption were calculated using the model Widianto et al. (2003).

Emission of $\mathrm{CH}_{4}$ and $\mathrm{N}_{2} \mathrm{O}$ in a wastewater plant was estimated using the formula adapted from IPCC 2006 and the inventory guidelines (Doorn et al. 2006; Kementerian Lingkungan Hidup 2012):

$$
\mathrm{CH}_{4} \text { emission }=\sum_{i}\left[\left(\mathrm{TOW}_{i}-S_{i}\right) E F_{i}-R_{i}\right]
$$

where: $T O W_{i}=$ total organically degradable material in wastewater from industry $i$ in inventory year, $\mathrm{kg} \mathrm{COD}$

$i=$ industrial sector

$S_{i}=$ organic component removed as sludge in inventory year, $\mathrm{kg}$ COD

$E F_{i}=$ emission factor for industry $\mathrm{i}, \mathrm{kg}$ $\mathrm{CH}_{4} / \mathrm{kg}$ COD for treatment/discharge pathway or system(s) used in inventory
$R_{i}=$ amount of $\mathrm{CH}_{4}$ recovered in inventory year, $\mathrm{kg} \mathrm{CH}_{4}$

Choosing emission factor (Doorn et al., 2006; Kementerian Lingkungan Hidup, 2012):

$$
E F_{j}=B_{o} \times M C F_{j}
$$

where: $E F_{j}=$ emission factor for each treatment/ discharge pathway or system, $\mathrm{kg} \mathrm{CH} / \mathrm{kg}$ COD

$j=$ each treatment/discharge pathway or system

$B_{o}=$ maximum $\mathrm{CH}_{4}$ producing capacity, $\mathrm{kg} \mathrm{CH} / 4 \mathrm{~kg} \mathrm{COD} \mathrm{MCFj}$

$M C F_{j}=$ methane correction factor (fraction) $=0.8$ (Doorn et al., 2006; Kementerian Lingkungan Hidup, 2012)

Organically degradable material in industrial wastewater (Doorn et al., 2006; Kementerian Lingkungan Hidup, 2012) :

$$
\operatorname{TOW}_{i}=P_{i} \times W_{i} \times \operatorname{COD}_{i}
$$

where: $T O W i=$ total biodegradable material in wastewater for industry i, kg COD

$i=$ industrial sector

$P_{i}=$ total industrial product for industrial sector i,

$W_{i}=$ wastewater generated, $\mathrm{m}^{3} / \mathrm{t}$ product $C O D_{i}=$ chemical oxygen demand (industrial degradable organic component in wastewater), $\mathrm{kg} \mathrm{COD} / \mathrm{m}^{3}$

$\mathrm{N}_{2} \mathrm{O}$ emissions from wastewater effluent:

$$
\begin{gathered}
\mathrm{N}_{2} \mathrm{O} \text { emission }= \\
N_{\text {effluent }} \times E F_{\text {effluent }} \times 44 / 28
\end{gathered}
$$


where: $\mathrm{N}_{2} \mathrm{O}$ emissions $=\mathrm{N}_{2} \mathrm{O}$ emissions in inventory, $\mathrm{kg} \mathrm{N} \mathrm{N}_{2} \mathrm{O}$

$N_{\text {effluent }}=$ nitrogen in the effluent discharged to aquatic environments, $\mathrm{kg} \mathrm{N}$

$E F_{\text {effluent }}=$ emission factor for $\mathrm{N}_{2} \mathrm{O}$ emissions from discharged to wastewater, $\mathrm{kg}$ $\mathrm{N}_{2} \mathrm{O}-\mathrm{N} / \mathrm{kg} \mathrm{N}, 0.005 \mathrm{~kg} \mathrm{~N} \mathrm{~N}_{2} \mathrm{O}-\mathrm{N} / \mathrm{kg}-\mathrm{N}$

The factor $44 / 28$ is the conversion of $\mathrm{kg}$ $\mathrm{N}_{2} \mathrm{O}-\mathrm{N}$ into $\mathrm{kg} \mathrm{N}_{2} \mathrm{O}$

The estimated emissions obtained from step 2 were analyzed using OpenLCA application with methodology CML (baseline) [v4.4, January 2015] to assess the environmental impact potential with boundary, as shown in Figure 2.

The final step was to implement the theoretical preliminary WWTP into amplang production system and assess its potential environmental impact using LCA.

\section{RESULT AND DISCUSSION}

\section{Data Inventory}

The fishing data was obtained from fishermen and fish collectors' financial statements during the June - August 2017 fishing period, as well as using the information from boat owners and fish collectors. The data obtained include the inputs of fuel and ice and the output of fish catch per species during the period of June - August 2017 (Table 3). The production process of amplang, fish cracker and sticks in outline consists of 4 stages, including fish receiving, stor- ing, processing and packaging. Mass balance of those 4 stages is presented in Table 4 .

\section{Life Cycle Impact Assessment}

The output of amplang production was analyzed using CML methodology (baseline) [v4.4, January 2015]. The results of the analysis show that the processing has potential environmental impacts in the categories of acidification, climate change, eutrophication and photochemical oxidation. This potential is the impact of indirect emissions on the consumption of electrical energy, the use of diesel fuel in the process of catching, the use of gas and frozen fish storage, and also wastewater generated.

Using the result of LCA analyses (Table 5), we also can see contribution of each process to impact categories, as shown in Figure 3.

\section{Acidification potential}

In the production system studied, the highest contributor of the acidification was fish catching and electricity consumption due to fossil fuels consumption of fishing vessels and power plants. The emissions generated by fishing vessel that contribute to acidification potential were $\mathrm{NO}_{\mathrm{x}}$ and $\mathrm{SO}_{\mathrm{x}}$, while power plants produced $\mathrm{NO}_{\mathrm{x}}$ and $\mathrm{SO}_{2}$. The fuels used in power plant were diesel and coal. According to Widiyanto et al. (2003), in order to generate $1 \mathrm{kWh}$ of electric energy, the $\mathrm{SO}_{2}$ and $\mathrm{NO}_{x}$ emissions produced by burning coal in power plants are greater than in the case of diesel. The $\mathrm{NO}_{x}$ contribution in $1 \mathrm{~kg}$ amplang production system was $6.826 \mathrm{E}^{-02} \mathrm{~kg}$ $\mathrm{SO}_{2}$ eq, while $\mathrm{SO}_{2}$ was $1.035 \mathrm{E}^{-02} \mathrm{~kg} \mathrm{SO}_{2}$ eq.

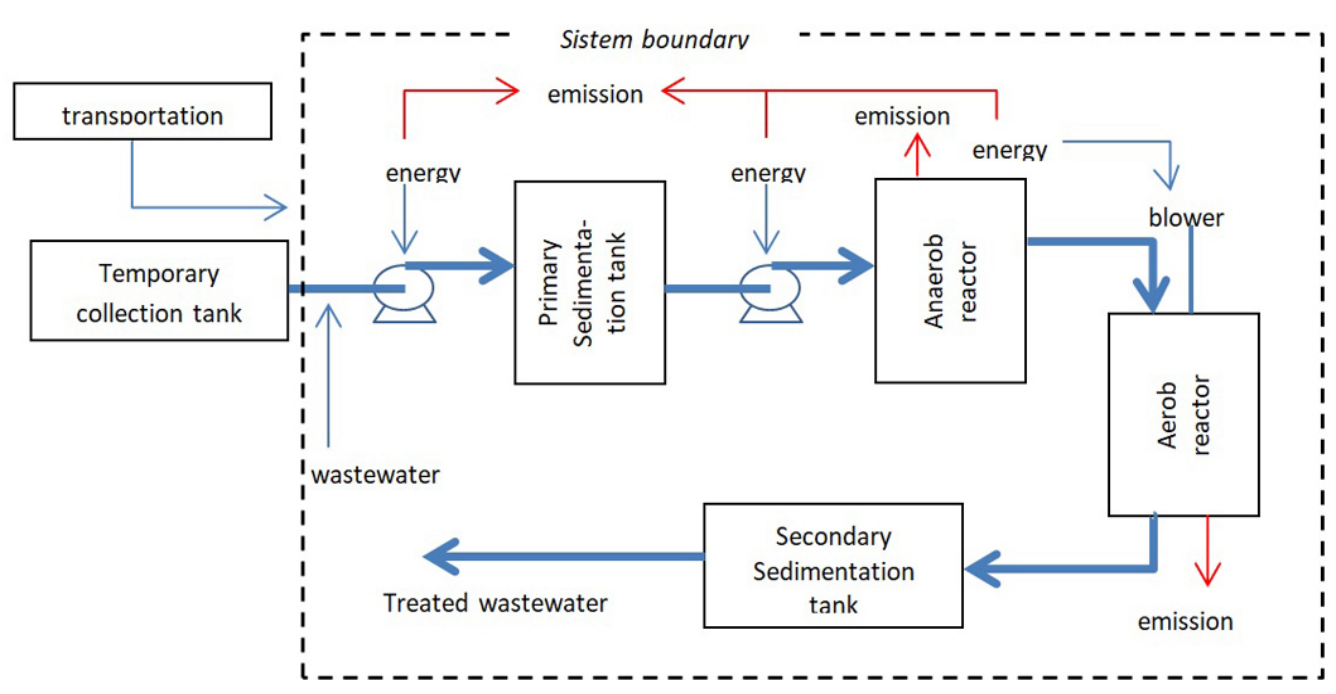

Fig. 2. WWTP's LCA boundary 
Table 3. Fishing yield of 7 studying object vessel in June - August 2017 periods

\begin{tabular}{|c|c|c|}
\hline \multirow{2}{*}{ Object } & \multicolumn{2}{|c|}{ Vessel's motor and capacity } \\
\hline & PS 1204 Tak, 15 GT & Dongfeng 4 Tak, 15 GT \\
\hline Trips & 33 & 27 \\
\hline Diesel consumption per trip (liter) & 250 & 250 \\
\hline Ice consumption per trip $(\mathrm{kg})$ & 1250 & 1250 \\
\hline \multicolumn{3}{|c|}{ HTSU } \\
\hline Tenggiri (kg) & $4,708.77$ & 4,592 \\
\hline Otek (kg) & 3,718 & 4,269 \\
\hline Telang (kg) & 2,375 & 2,473 \\
\hline Kakap merah $(\mathrm{kg})$ & 111.5 & 104 \\
\hline Senangin $(\mathrm{kg})$ & 620.5 & 713.12 \\
\hline Other fish (kg) & $3,013.8$ & 3,493 \\
\hline Total $(\mathrm{kg})$ & $14,547.57$ & $15,644.12$ \\
\hline
\end{tabular}

Tabel 4. Mass balance of amplang processing

\begin{tabular}{|c|c|c|c|c|}
\hline \multicolumn{2}{|c|}{ Input } & \multirow{2}{*}{$\begin{array}{c}\text { Processing phase } \\
\text { Mixing I }\end{array}$} & \multicolumn{2}{|c|}{ Output } \\
\hline $\begin{array}{ll} & \text { Surimi } \\
\text { - } & \text { Eggs } \\
\text { - } & \text { Seasoning } \\
\text { - } & \text { Energy } \\
\end{array}$ & $\begin{array}{c}4,320 \mathrm{~kg} \\
1,728 \mathrm{~kg} \\
432 \mathrm{~kg} \\
108 \mathrm{kWh} \\
\end{array}$ & & $\begin{array}{l}\text { - Dough } 1 \\
\text { - Eggshell } \\
\text { - Energy }\end{array}$ & $\begin{array}{c}6,315.84 \mathrm{~kg} \\
164.16 \mathrm{~kg} \\
108 \mathrm{kWh}\end{array}$ \\
\hline $\begin{array}{ll}\text { - } & \text { Dough } 1 \\
\text { - } & \text { Tapioca } \\
\text { - } & \text { Energy }\end{array}$ & $\begin{array}{l}6,315.84 \mathrm{~kg} \\
7,200 \mathrm{~kg} \\
243 \mathrm{kWh}\end{array}$ & Mixing II & $\begin{array}{l}\text { - Dough } 2 \\
\text { - Energy }\end{array}$ & $\begin{array}{c}13,515.84 \mathrm{~kg} \\
243 \mathrm{kWh}\end{array}$ \\
\hline - Dough 2 & $13,515.84 \mathrm{~kg}$ & Shaping & - Raw amplang & $13,515.84 \mathrm{~kg}$ \\
\hline $\begin{array}{ll}\text { - } & \text { Raw amplang } \\
\text { - } & \text { Cooking oil } \\
\text { - } & \text { LPG }\end{array}$ & $\begin{array}{c}13,515.84 \mathrm{~kg} \\
5,760 \mathrm{liter} \\
1,728 \mathrm{~kg}\end{array}$ & Frying & $\begin{array}{l}\text { - Amplang } \\
\text { - Steam } \\
\text { - Used cooking oil } \\
\text { - Energy }\end{array}$ & $\begin{array}{c}8,640 \mathrm{~kg} \\
4,875.84 \mathrm{~kg} \\
2,160 \text { liter } \\
8.17 \mathrm{E}-02 \mathrm{TJ}\end{array}$ \\
\hline $\begin{array}{l}\text { - Amplang } \\
\text { - Packaging Plastic } \\
\text { - Energy }\end{array}$ & $\begin{array}{c}8,640 \mathrm{~kg} \\
188 \mathrm{~kg} \\
173 \mathrm{kWh}\end{array}$ & Packaging & $\begin{array}{l}\text { - Amplang packaged } \\
\text { - Energy }\end{array}$ & $\begin{array}{c}8,828 \mathrm{~kg} \\
173 \mathrm{~h}\end{array}$ \\
\hline
\end{tabular}

Table 5. Impact category of amplang production process

\begin{tabular}{|l|c|c|}
\hline \multicolumn{1}{|c|}{ Impact category } & Reference unit & Result amplang \\
\hline Acidification potential - average Europe & $\mathrm{kg} \mathrm{SO}$ eq. & 0.079 \\
\hline Climate change - GWP100 & $\mathrm{kg} \mathrm{CO}$ eq. & 9.66 \\
\hline Eutrophication - generic & $\mathrm{kg}$ PO4-- eq. & 0.02 \\
\hline Human toxicity - HTP inf & kg ethylene eq. & 0.17 \\
\hline Photochemical oxidation - high Nox & & 0.0015 \\
\hline
\end{tabular}

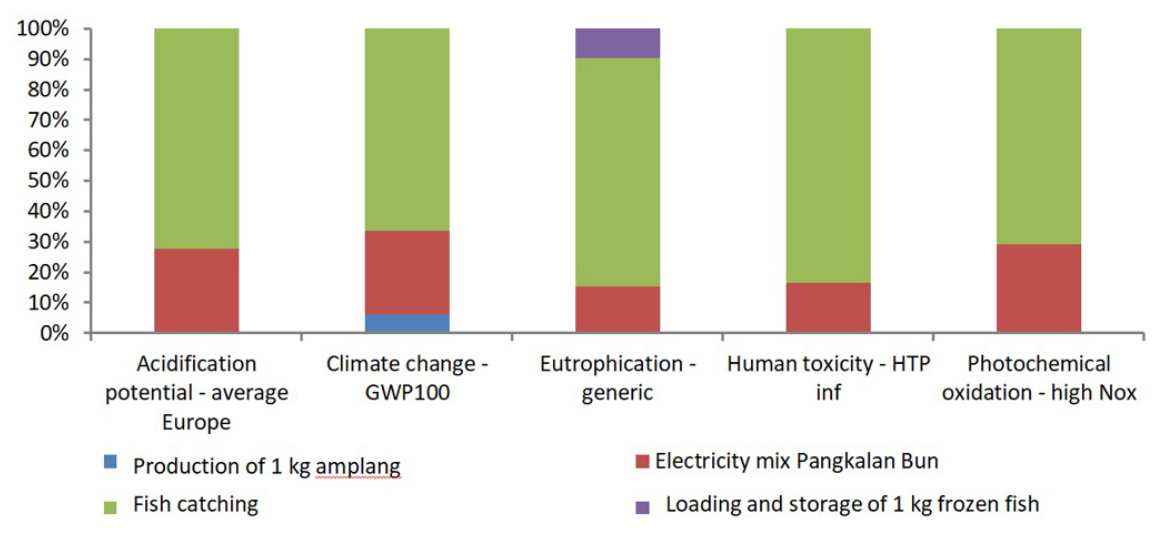

Fig. 3. The contribution of process to impact 


\section{Climate change - GWP100}

In the system studied, $\mathrm{CO}_{2}, \mathrm{CH}_{4}$ and $\mathrm{N}_{2} \mathrm{O}$ emissions were emitted by fishing vessel, power generation and little in the production process. In these three stages, emissions were released by burning the fuel of fishing vessels, power plants and LPG burning. The greenhouse gas emissions produced from fuel consumption on fishing vessels amounted to $6.41 \mathrm{~kg} \mathrm{CO}_{2}$ eq, power plants $2.65 \mathrm{~kg} \mathrm{CO}_{2}$ eq and cooking processes using LPG gas stoves $5.98 \mathrm{E}^{-01} \mathrm{~kg} \mathrm{CO}_{2}$ eq. The contribution of $\mathrm{CO}_{2}$ to climate change potential reached as much as $9.555 \mathrm{~kg}, \mathrm{CH}_{4} 2.245 \mathrm{E}^{-03} \mathrm{~kg} \mathrm{CO}_{2}$ eq, and $\mathrm{N}_{2} \mathrm{O}$ $2.561 \mathrm{E}^{-02} \mathrm{~kg} \mathrm{CO}_{2}$ eq.

\section{Eutrophication potential}

Eutrophication factors emitted in the process of fish catching amounted to about $1.48 \mathrm{E}^{-02} \mathrm{~kg} \mathrm{PO}_{4}$ eq, fish receipting $1.92 \mathrm{E}^{-03} \mathrm{~kg} \mathrm{PO}_{4} \mathrm{eq}$, amplang frying $7.01 \mathrm{E}^{-05} \mathrm{~kg} \mathrm{PO}_{4} \mathrm{eq}$ and power plants $2.93 \mathrm{E}^{-03}$ $\mathrm{kg} \mathrm{PO}_{4}$ eq. The emission factors included $\mathrm{N}_{2} \mathrm{O}$ and $\mathrm{NO}_{\mathrm{x}}$ emitted to air, emissions of ammonia to water, $\mathrm{BOD}, \mathrm{COD}$, nitrate, nitrite, nitrogen, phosphate and phosphorus (Table 6). $\mathrm{N}_{2} \mathrm{O}$ in the SME production system was only emitted by the electricity generation process. On the other hand, $\mathrm{NO}_{\mathrm{x}}$ was generated from LPG burning on gas stoves, diesel consumption as a source of energy for fishing vessels and fossil fuels consumption (diesel and coal) in power plants. Meanwhile, all emissions to water are generated from the washing stage of the fish receiving and storage process.

\section{Human toxicity potential}

$\mathrm{NO}_{\mathrm{x}}$ was the highest factor of the human toxicity impact category. $\mathrm{NO}_{\mathrm{x}}$ in the human toxicity category has respiratory distress potential (Najjar 2011; WHO 2005). As a result of the study, $\mathrm{NO}_{\mathrm{x}}$ was mostly generated in the fish catching process due to the diesel fuel combustion in ship engines. In the production chain of $1 \mathrm{~kg}$ of amplang, at the fishing stage, $\mathrm{NO}_{\mathrm{x}}$ of $1.14 \mathrm{E}^{-01} \mathrm{~kg}, 1.14 \mathrm{E}^{-01} \mathrm{~kg}$, and $1.36 \mathrm{E}^{-01} \mathrm{~kg}$ were produced, respectively. As previously mentioned, $\mathrm{NO}_{\mathrm{x}}$ contributes to three impact categories: acidification, eutrophication and human toxicity. On the basis of the analysis results obtained from this study, $\mathrm{NO}_{\mathrm{x}}$ contribute to the category of human toxicity impact the most.

\section{Photochemical oxidation potential}

The contributors to photochemical oxidation impact potential of $1 \mathrm{~kg}$ amplang production system include: $\mathrm{CO}$ about $1.084 \mathrm{E}^{-03} \mathrm{~kg}$ ethylene eq, methane $5.389 \mathrm{E}^{-07} \mathrm{~kg}$ ethylene eq and $\mathrm{SO}_{2}$ $4.139 \mathrm{E}^{-04}$. Out of the three compounds, carbon monoxide was the highest contributor.

\section{Biofilter Anaerobic-aerobic processes}

Wastewater treatment with anaerobic-aerobic biofilter process is a combination of anaerobic and aerobic processes. This method has high decomposition efficiency of organic material but requires relatively low amounts of energy. In this process, $\mathrm{CO}_{2}$ and $\mathrm{CH}_{4}$ gases are produced in the anaerobic phase, whereas in the aerobic phase, $\mathrm{NH}_{3}$ breaks down into nitrite and nitrate, and $\mathrm{H}_{2} \mathrm{~S}$ becomes sulfate. In this study, LCA analyses only consider the energy use and emissions generated that are $\mathrm{CH}_{4}$ and $\mathrm{N}_{2} \mathrm{O}$. The $\mathrm{CO}_{2}$ also generated in this process is not considered due to it is biogenic origin (Kementerian Lingkungan Hidup 2012).

The SME studied is located in the middle of a fairly dense settlement, similarly to several other fish processing SMEs. The problems faced by these SMEs are the lack of wastewater treatment and direct discharge of the wastewater into the river. Considering the high organic matter content

Table 6. Characteristic of Mackerel processing wastewater

\begin{tabular}{|c|c|c|c|}
\hline \multirow{2}{*}{ No } & Parameter & \multicolumn{2}{|c|}{ Result } \\
\cline { 3 - 4 } & & Amount $(\mathrm{mg} / \mathrm{l})$ & Environmental burdon (kg/ton) \\
\hline 1 & $\mathrm{BOD}$ & $1,051.5$ & $2.52 \mathrm{E}+00$ \\
\hline 2 & $\mathrm{COD}$ & 1,741 & $4.18 \mathrm{E}+00$ \\
\hline 3 & $\mathrm{NO}_{2}$ & 0.065 & $1.56 \mathrm{E}-04$ \\
\hline 4 & $\mathrm{NO}_{3}$ & 10.0 & $2.40 \mathrm{E}-02$ \\
\hline 5 & $\mathrm{NH}_{3}$ & 0,170 & $4.08 \mathrm{E}-04$ \\
\hline 6 & $\mathrm{P}$ total & 37.1 & $8.90 \mathrm{E}-02$ \\
\hline 7 & $\mathrm{PO}-\mathrm{P}$ & 36.8 & $8.83 \mathrm{E}-02$ \\
\hline 8 & $\mathrm{~N}$ total & 1,741 & $4.18 \mathrm{E}+00$ \\
\hline 9 & Wastewater $\left(\mathrm{m}^{3} / \mathrm{ton}\right)$ & & 2.4 \\
\hline
\end{tabular}


characteristic of the fish processing wastewater, location and IPAL requirement for community or SMEs, this study selected the anaerobic-aerobic biofilter method to be analyzed.

In the amplang industry, water was used for clean fish but not as one of the raw materials in the processing. Thus, the volume of wastewater is considered equal to the volume of water used. On the basis of volume and composition of wastewater, wastewater treatment plant (WWTP) was preliminary designed as follows (Table 7):

\section{Comparison of amplang product system with and without wastewater treatment}

Figure 4 shows that there is a little difference within four impact categories due to implementation of BWRO system water treatment and waste treatment. A relatively high decrease of potential impact is only seen in the eutrophication category. The reason of this condition is an increasing of electricity consumption due to water treatment purposes and reduction of emissions to water in the presence of WWTP (Table 8).

Table 8 above shows that if a WWTP applied, the process of fish receiving no longer contributes to eutrophication. However, potential impacts still arise in the waste treatment process, even though the value is much smaller. Due to waste treatment process, the emissions of ammonia, BOD,
$\mathrm{COD}$, nitrate and nitrogen to water contributed to the impact of eutrophication, while ammonia and ammonium contributed from the water treatment process . The highest contribution to the eutrophication impact category actually comes from the process of fish catching, as a consequence of fossil fuel consumption. This process contributes to eutrophication with emissions to air of $\mathrm{NO}_{\mathrm{x}}$ by $0.0280 \mathrm{~kg} \mathrm{PO}_{4}^{-}$eq.

The process of energy generation and fish catching was the largest contributor to the five impact categories, as a result of fossil fuel consumption to meet energy needs. The electricity demand on fish receipting process was estimated to increase from $0.173 \mathrm{kWh} / \mathrm{kg}$ of frozen fish to $0.1778 \mathrm{kWh} / \mathrm{kg}$ of frozen fish. On the other hand, the average requirement of diesel fuel in the catching process equals 1.29 liters per kg of mackerel fish. One of the efforts to decrease the specific energy needs of the fishing process is by increasing the catch of fishermen per trip, as an attempt to optimize the utilization of energy resources, in addition to substituting the transfer of fuel with a more environmentally friendly energy source.

\section{Sensitivity analysis}

As described previously, the implementation of water and wastewater treatment has a major effect on the fish receiving process; thus, the sen-

Table 7. Portable WWTP design input output per day

\begin{tabular}{|c|c|c|c|c|c|}
\hline $\begin{array}{c}\text { Parameter } \\
\text { Input }\end{array}$ & Unit & Value & $\begin{array}{c}\text { Parameter } \\
\text { Output }\end{array}$ & Unit & Value \\
\hline Influent rate & $\mathrm{m}^{3} / \mathrm{d}$ & 3.21 & Product: & & \\
\hline $\mathrm{BOD}_{\text {in }}$ & $\mathrm{kg}$ & 3.375315 & Treated wastewater & $\mathrm{m}^{3} / \mathrm{d}$ & 3.21 \\
\hline $\mathrm{COD}_{\text {in }}$ & $\mathrm{kg}$ & 5.58861 & Recovered $\mathrm{CH}_{4}$ & $\mathrm{~kg}$ & 0.51 \\
\hline $\mathrm{NO}_{3}$ in & $\mathrm{kg}$ & 10 & Emission/waste: & & \\
\hline $\mathrm{N}$-total ${ }_{\text {in total }}$ & $\mathrm{kg}$ & 1741 & $\mathrm{NO}_{3 \text { out }}$ & $\mathrm{Kg}$ & 0.024075 \\
\hline $\mathrm{NH}_{3 \text { in }}$ & $\mathrm{kg}$ & 0.0005457 & N-total ${ }_{\text {out I }}$ & $\mathrm{Kg}$ & 3.406261514 \\
\hline \multirow[t]{4}{*}{ Energy } & kWh & 1.147 & $\mathrm{NH}_{3 \text { out }}$ & $\mathrm{Kg}$ & 0.000544495 \\
\hline & & & BOD out & $\mathrm{kg}$ & 0.335347438 \\
\hline & & & COD out & $\mathrm{kg}$ & 0.717337114 \\
\hline & & & $\mathrm{N}_{2} \mathrm{O}$ & $\mathrm{kg}$ & 0.0373 \\
\hline
\end{tabular}

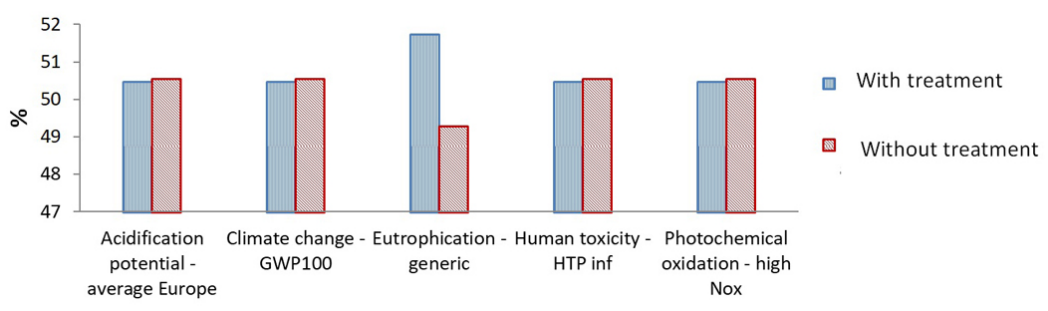

Fig. 4. Comparison of amplang product system with and without wastewater treatment 
Table 8. Process contribution to impact category

\begin{tabular}{|c|c|c|c|c|c|c|}
\hline Impact category & Referency unit & $\begin{array}{l}\text { Receipting and } \\
\text { storing } 1 \mathrm{~kg} \text { of } \\
\text { frozen fish }\end{array}$ & $\begin{array}{l}\text { Electricity mix } \\
\text { Pangkalan Bun }\end{array}$ & Fish catching & $\begin{array}{c}\text { Wastewater } \\
\text { treatment }\end{array}$ & $\begin{array}{l}\text { BWRO } \\
1.050 \mathrm{~m}^{3}\end{array}$ \\
\hline \multicolumn{7}{|c|}{ Without water and wastewater treatment } \\
\hline $\begin{array}{l}\text { Acidification } \\
\text { potential - average Europe }\end{array}$ & $\mathrm{kg} \mathrm{SO}_{2}$ eq. & - & 3.33E-02 & 9.04E-02 & - & - \\
\hline Climate change - GWP100 & $\mathrm{kg} \mathrm{CO}_{2}$ eq. & - & $4.09 \mathrm{E}+00$ & $1.02 \mathrm{E}+01$ & - & - \\
\hline Eutrophication - generic & $\mathrm{kg} \mathrm{PO}_{4}^{-2}$ eq. & $3,05, \mathrm{E}-03$ & 4.53E-03 & 2.35E-02 & - & - \\
\hline Human toxicity - HTP inf & kg 1,4-DCB eq. & - & $4.28 \mathrm{E}-02$ & $2.29 \mathrm{E}-01$ & - & - \\
\hline $\begin{array}{l}\text { Photochemical } \\
\text { oxidation - high } \mathrm{NO}_{x}\end{array}$ & $\mathrm{~kg}$ ethylene eq. & - & $6.60 \mathrm{E}-04$ & $1.69 \mathrm{E}-03$ & - & - \\
\hline \multicolumn{7}{|c|}{ With water and wastewater treatment } \\
\hline $\begin{array}{l}\text { Acidification } \\
\text { potential - average Europe }\end{array}$ & $\mathrm{kg} \mathrm{SO}_{2}$ eq. & - & 3.34E-02 & 9.05E-02 & - & - \\
\hline Climate change - GWP100 & kg COZ eq. & - & $4.11 \mathrm{E}+00$ & $1.02 \mathrm{E}+01$ & - & - \\
\hline Eutrophication - generic & $\mathrm{kg} \mathrm{PO}_{4}^{-2}$ eq. & - & 4.55E-03 & 2.35E-02 & $1.49 \mathrm{E}-03$ & 2.88E-05 \\
\hline Human toxicity - HTP inf & kg 1,4-DCB eq. & - & 4.29E-02 & $2.29 \mathrm{E}-01$ & - & - \\
\hline $\begin{array}{l}\text { Photochemical } \\
\text { oxidation - high } \mathrm{NO}_{\mathrm{x}}\end{array}$ & & - & $6.63 E-04$ & 1.69E-03 & - & - \\
\hline
\end{tabular}

sitivity analysis is limited to this process. The sensitivity analysis aims to test the differences that may occur when the input value of fish raw materials is changed in the process of receiving fish. This sensitivity analysis is based on high fluctuations in the fish availability. This fluctuation results in variable power consumption, especially in the frozen fish storage stage. In addition, fluctuations in raw materials also impact the water consumption.

Figure 5 shows that the categories of climate change impacts are the most sensitive parameters due to the increase in the electricity consumption along with the growing amount of raw materials that must be stored in a frozen state. In the SME, the amount of production depends on the order received, while the duration of storage of raw materials depends on the order and stock of the product. In addition, the acceptance of raw materials can be done when stocks of frozen fish still exist. With the principle of first in first out, the later fish must be kept frozen for longer until the stock of the earlier fish were used up.

More specifically, the sensitivity of the five categories of impacts to changes in raw inputs of fish is shown in Figure 5 below.

The second sensitive parameter is human toxicity, which is contributed by $\mathrm{NO}_{\mathrm{x}}, \mathrm{PM}_{10}$, and $\mathrm{SO}_{2}$. They are the result of burning fossil fuels. $\mathrm{NO}_{\mathrm{x}}$ comes from power plants and fishing vessels, $\mathrm{PM}_{10}$ from fishing vessels and $\mathrm{SO}_{2}$ from power plants. The largest contributor towards the human toxicity in fish receipt $1500 \mathrm{~kg}$ is $\mathrm{NO}_{\mathrm{x}}$ that is equal to $281.3885807 \mathrm{~kg}$ 1,4-dichlorobenzene eq.

The impact category of eutrophication was less sensitive to the fluctuation in the amount of frozen fish it receives. This can be due to portable waste treatment. In this processing, the volume of wastewater input can be adjusted according to its capacity, then it can be expected that the quality of treated wastewater would not fluctuate much.

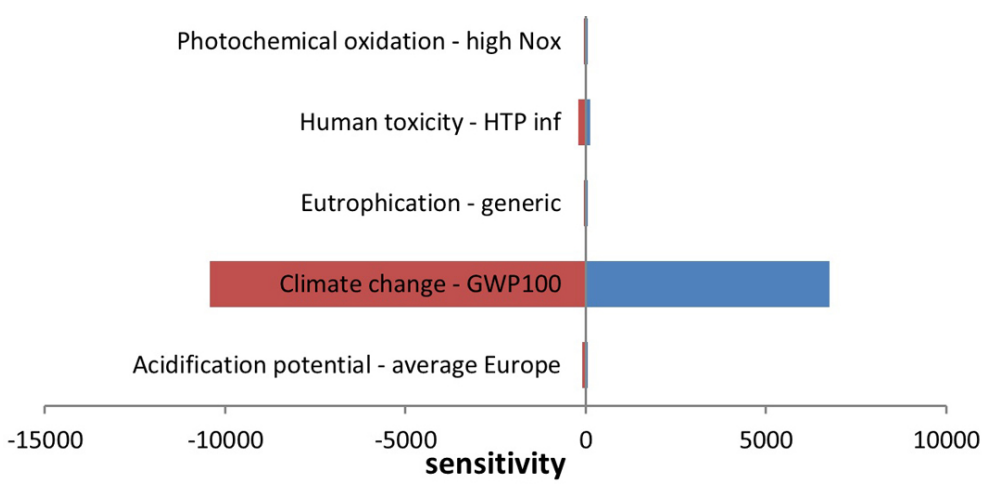

Fig. 5. Sensitivity of impact category potential by raw fish input fluctuation 


\section{CONCLUSION}

The system product of fish-based amplang, in its life cycle, as well as fish processing in general, requires considerable amounts of water and energy. These water and energy requirements have implications for the generation of waste and gas emissions. This study showed that the life cycle production of the amplang from cradle to gate has the environmental impact on the acidification potential, climate change, eutrophication, human toxicity and photochemical oxidation categories. The processes that contribute the most to the impact category are power generation and fishing as a consequence of using fossil fuels (diesel and coal) as an energy source.

The amplang production process itself produces direct emissions from wastewater discharged into rivers. This wastewater contains COD, BOD and nitrogen in the amounts that are high enough to contribute to eutrophication impact categories.

The results of analysis in this study indicate that the implementation of waste treatment of anaerobic-aerobic biofilter method can decrease the eutrophication impact category. As methane produced by WWTP can be recovered, only $\mathrm{N}_{2} \mathrm{O}$ increases the climate change potential, in addition to $\mathrm{N}_{2} \mathrm{O}$ still contributing to eutrophication with the remaining COD.

\section{REFERENCES}

1. Arvanitoyannis, I.S., \& Kassaveti, A. 2008. Fish industry waste: Treatments, environmental impacts, current and potential uses. International Journal of Food Science and Technology, 43(4), 726-745. https://doi.org/10.1111/j.1365-2621.2006.01513.x

2. Doorn, M.R.J., Towprayoon, S., Vieira, S.M.M., Irving, W., Palmer, C., Pipatti, R., \& Wang, C. 2006. Wastewater Treatment and Discharge. IPCC Guidelines for National Greenhouse Gas Inventories. Prepared by the National Greenhouse Gas Inventories Programme. IGES, Japan.

3. Duangpaseuth, SDas, Q., Chotchamlong, N., Ariunbaatar, J., Khunchornyakong, A., \& Prashanthini, V. 2010. Seafood Processing.

4. Foley, J., de Haas, D., Hartley, K., \& Lant, P. 2010. Comprehensive life cycle inventories of alternative wastewater treatment systems. Water Research, 44(5), 1654-1666. https://doi.org/10.1016/j.watres.2009.11.031

5. Glick, S., Guggemos, A.A., \& Asce, A.M. 2005. Rethinking Wastewater-Treatment Infrastructure : Case Study Using Life-Cycle Cost and Life-Cy- cle Assessment to Highlight Sustainability Considerations, (Coldham 1996), 1-8. https://doi. org/10.1061/(ASCE)CO.1943-7862.0000762.

6. Hall, G.M., \& Kose, S. 2014. Fish Processing Installations: Sustainable Operation. In I.S. Boziaris (Ed.), Seafood Processing: Technology, Quality and Safety (pp. 1-488). West Sussex: John Wiley \& Sons. https://doi.org/10.1002/9781118346174

7. International assessment - Principles and framework 1997. International Organization for Standardization.

8. Kalbar, P.P., Karmakar, S., \& Asolekar, S.R. 2013. Assessment of wastewater treatment technologies : life cycle approach, 27(3), 261-268. https://doi. org/10.1111/wej.12006

9. Kementerian Lingkungan Hidup 2012. Pedoman Penyelenggaraan Inventarisasi Gas Rumah Kaca Nasional Buku II. Jakarta: Kementerian Lingkungan Hidup (in Indonesian).

10. Midgley, P., Wang, M., Berntsen, T., Bey, I., Brasseur, G., Buja, L., Yantosca, R. 2001. Atmospheric Chemistry and Grenhouse Gases. In Climate Change 2001: The Scientific Basis. IPCC. Retrieved from https://www.ipcc.ch/ipccreports/tar/ wg1/pdf/TAR-04.PDF

11. Rizaldi Boer, Dewi, R. G., Siagian, U. W., Ardiansyah, M., Surmaini, E., Ridha, D. M., et al. 2012. Pedoman Penyelenggaraan Inventarisasi Gas Rumah Kaca Nasional Buku Ii. Metodologi Penghitungan Tingkat Emisi Gas Rumah Kaca Kegiatan Pengadaan Dan Penggunaan Energi (Vol. 1). Kementerian Lingkungan Hidup (In indonesian).

12. Said, N.I. 2017. Teknologi Pengolahan Air Limbah. Jakarta: Penerbit Erlangga (In indonesian).

13. Snip, L.J.P. 2010. Quantifying the greenhouse gas emissions of wastewater treatment plants. Wageningen University. Retrieved from http://modeleau.fsg.ulaval.ca/fileadmin/modeleau/documents/ Publications/MSc_s/sniplaura_msc.pdf

14. Suhadi, D.R., \& Febrina, A.S. 2013. Pedoman Teknis Penyusunan Inventarisasi Emisi Pencemar Udara Di Perkotaan, 153 (In indonesian).

15. Sunny, N., \& Mathai P.L. 2013. Physicochemical process for fish processing wastewater. International Journal of Innovative Research in Science, Engineering and Technology, 2(4), 901-905.

16. Tay, J.-H., Show, K.-Y., \& Hung, Y.-T. 2004. Seafood Processing Wastewater Treatment. In: L.K. Wang, Y. Hung, H.H. Lo, \& C. Yapijakise (Eds.), Handbook of industrial and hazardous wastes treatment ( $\left.2^{\text {nd }} \mathrm{ed}.\right)$. New York, Basel: Marcel Dekker, Inc., 29-66.

17. Widiyanto, A., Kato, S., \& Maruyana, N. 2003. Environmental Impact Analysis of Indonesian Electric Generation Systems. JSME International Journal Series B, 46(4), 650-659. https://doi. org/10.1299/jsmeb.46.650. 